\title{
Ketiadaan Batas Waktu Suspensi dan Implikasinya Terhadap Perlindungan Investor Pasar Modal Indonesia
}

\author{
Inda Rahadiyan dan Diah Ayu Ambarsari \\ Fakultas Hukum Universitas Islam Indonesia \\ Jln. Tamansiswa No. 158 Yogyakarta \\ indarahadiyan1@gmail.com; diahayuas17@gmail.com
}

Received: 12 Januari 2018; Accepted: 8 Mei 2018; Published: 5 Nopember 2018

DOI: 10.20885/iustum.vol25.iss2.art5

\begin{abstract}
The problems in this study include First, how is the regulation of suspension and its implications on the legal certainty for listed companies? Sekond, what are the implications of the absence of time limit for suspension on investor protection? Third, how is the time limit for suspension in the United States? This study used normative legal method. The results of the study indicated that First, the absence of regulation regarding the time limit for suspension by the Indonesia Stock Exchange results in the absence of legal certainty for listed companies subject to suspension. Sekond, the absence of time limit for suspension has an impact in the form of a low legal protection for investors. Third, Suspension in the United States imposed by the Securities Exchange Commission (SEC) is limited to a certain period of time. The regulated time limit for imposing suspensions in the United States provides more legal certainty for listed companies and more legal protection for investors.
\end{abstract}

Keywords: Suspension; legal protection; capital market; Indonesia

\section{Abstrak}

Permasalahan yang dikaji dalam penelitian ini meliputi pertama, bagaimana pengaturan sanksi suspensi dan implikasinya terhadap kepastian hukum bagi perusahaan tercatat? Kedua, bagaimana implikasi atas ketiadaan batas waktu pengenaan suspensi terhadap perlindungan investor?Ketiga, bagaimana pengaturan batas waktu pengenaan sanksi suspensi di Amerika Serikat? Penelitian dilakukan dengan menggunakan metode yuridis normatif. Hasil penelitian menyimpulkan bahwa Pertama, Ketiadaan pengaturan mengenai batas waktu pengenaan suspensi oleh Bursa Efek Indonesia mengakibatkan ketiadaan jaminan kepastian hukum bagi perusahaan tercatat yang terkena sanksi suspensi. Kedua, Ketiadaan batas waktu pengenaan suspensi berdampak pada masih lemahnya perlindungan hukum bagi investor. Ketiga, Pengenaan sanksi suspensi di Amerika Serikat oleh Securities Exchange Commission (SEC) dibatasai selama jangka waktu tertentu. Pengaturan mengenai batas waktu pengenaan suspensi di Amerika Serikat lebih memberikan jaminan kepastian hukum bagi perusahaan tercatat sekaligus lebih menjamin perlindungan hukum bagi investor.

Kata-Kata Kunci: Suspensi; perlindungan hukum; pasar modal; Indonesia 


\section{Pendahuluan}

Pada umumnya perusahaan-perusahaan yang telah melakukan penawaran umum $^{1}$ juga akan melakukan pencatatan efek (listing) ${ }^{2}$ di Bursa Efek. ${ }^{3}$ Perusahaanperusahaan yang telah listing selanjutnya disebut sebagai perusahaan tercatat (listed company). ${ }^{4}$ Efek dari perusahan-perusahaan tercatat inilah yang kemudian dapat diperdagangkan dengan memanfaatkan sarana dan prasarana Bursa.

Setiap perusahaan tercatat dapat melakukan perdagangan efek di pasar sekunder. Pengertian pasar sekunder dalam konteks ini mengacu pada suatu pasar yang mewadahi kegiatan jual beli atas efek setelah masa penjualan pada pasar perdana berakhir. ${ }^{5}$ Pada pasar sekunder ini harga efek dari perusahaan tercatat ditentukan berdasarkan kekuatan penawaran dan permintaan.

Perusahaan tercatat yang telah melakukan pencatatan efek wajib mematuhi seluruh peraturan Bursa Efek. Bursa Efek sebagai Self Regulatory Organization $(S R O)^{6}$ memiliki wewenang untuk membuat peraturan-peraturan bagi seluruh kegiatan yang terjadi di dalam bursa. Peraturan-peraturan yang dibuat oleh Bursa terutama dimaksudkan untuk mewujudkan perdagangan efek yang teratur, wajar dan efisien.7 Peraturan Bursa Efek memiliki kekuatan hukum mengikat bagi setiap

${ }^{1}$ Penawaran umum merupakan terjemahan dari istilah going public yang dikenal secara universal. Black's Law Dictionary mendifinisikan istilah going public sebagai: the process by which a corporation issues its first stock for public purchase. Also, when a private corporation becomes a public corporation. Said of a business whan its shares become traded to the general public, rather than being closely held by relatively few stockholders. Baca: Henry Champel Black, Black's Law Dictionary, Sixth Edition, ST. Paull, Minn, 1990, hlm. 691.

${ }^{2}$ Kegiatan pencatatan efek (listing) bagi Emiten yang telah melakukan penawaran umum di pasar primer bukanlah suatu kewajiban. Namun demikian, pencatatan efek hampir selalu dilakukan oleh setiap Emiten yang telah melakukan penawaran umum. Setelah Emiten melakukan pencatatan efek ke dalam suatu bursa efek, efek emiten tersebut dapat diperdagangkan di dalam bursa di mana efek tersebut dicatatkan. Uraian secara lebih mendalam mengenai hal ini baca: Hamud M. Balfaz, Hukum Pasar Modal di Indonesia, PT. Tata Nusa, Jakarta, 2010, hlm. 308.

${ }^{3}$ Tjiptono Darmaji dan Hendy M. Fakhruddin, Pasar Modal Di Indonesia Pendekatan Tanya Jawab, Edisi Pertama, Salemba Empat, Jakarta, 2001, hlm. 58.

4 Definisi perusahaan tercatat menurut Keputusan Direksi PT Bursa Efek Jakarta Nomor: Kep308/BEJ/07-2004 tentang Peraturan Nomor I-I Tentang Penghapusan Pencatatan (Delisting) dan Pencatatan Kembali (Relisting) Saham di Bursa adalah Emiten atau perusahaan publik yang Efeknya tercatat di bursa.

${ }^{5}$ Uraian secara lebih mendalam mengenai pasar sekunder ini, baca: Inda Rahadiyan, Pokok-Pokok Hukum Pasar Modal di Indonesia, UII Press, Yogyakarta, 2017, hlm. 102-105

6 Self Regulatory Organization (SRO) adalah lembaga yang diberi kewenangan untuk membuat peraturan yang mengatur para anggotanya. Baca: Iswi Hariyani dan R. Serfianto, Buku Pintar Hukum Pasar Modal: Strategi Tepat Investasi Saham, Obligasi, Waran, Right, Opsi, Reksadana dan Produk Pasar Modal Syariah, Visimedia, Jakarta, 2001, hlm. 21. Uraian secara lebih mendasar mengenai SRO dalam pasar modal baca pula: John Carson, Self Regulation in Securities Markets, The World Bank, Policy Research Working Paper Number 5542, January 2011.

${ }^{7}$ Terwujudnya perdagangan efek yang teratur, wajar dan efisien merupakan tujuan dari kegiatan pembinaan, pengaturan serta pengawasan pasar modal sebagaimana ditentukan dalam Pasal 4 Undang-Undang Nomor 8 Tahun 1995 tentang Pasar Modal. 
pelaku pasar modal. ${ }^{8} \mathrm{Hal}$ demikian juga berlaku di Indonesia atas setiap peraturan yang dibuat oleh Bursa Efek Indonesia (BEI).

Salah satu substansi peraturan yang dibuat oleh BEI adalah peraturan mengenai kewajiban-kewajiban perusahaan tercatat. Dua di antara kewajiban perusahaan tercatat yang ditentukan oleh BEI yakni kewajiban melaksanakan keterbukaan informasi ${ }^{9}$ dan kewajiban melakukan pembayaran biaya pencatatan efek. ${ }^{10}$ Kewajiban dimaksud sebagaimana diatur dalam Keputusan Direksi PT Bursa Efek Indonesia Nomor Kep-00001/BEI/01-2014 tentang Pencatatan Saham dan Efek Bersifat Ekuitas Selain Saham yang Diterbitkan oleh Perusahaan Tercatat. ${ }^{11}$

Berbagai bentuk sanksi dapat dikenakan kepada perusahaan tercatat yang melanggar peraturan bursa. Salah satu sanksi yang dapat dikenakan kepada perusahaan tercatat yakni sanksi suspensi. ${ }^{12}$ Istilah suspensi mengacu pada tindakan penghentian sementara aktivitas perdagangan efek perusahaan tercatat. ${ }^{13}$ Tindakan suspensi oleh BEI mengakibatkan efek perusahaan tercatat tidak dapat diperdagangkan melalui sarana dan prasarana Bursa sebagaimana mestinya.

Sanksi suspensi yang berkepanjangan selama kurun waktu dua puluh empat bulan dapat berlanjut dengan pengenaan tindakan penghapusan pencatatan saham secara paksa (forced delisting) atas efek perusahaan tercatat oleh BEI. ${ }^{14}$ Hal demikian sesuai dengan Keputusan Direksi PT Bursa Efek Jakarta Nomor: Kep-308/Bej/072004 tentang Peraturan Nomor I-I tentang Penghapusan Pencatatan (Delisting) Dan Pencatatan Kembali (Relisting) Saham Di Bursa. Keputusan tersebut menentukan

${ }^{8}$ Tjiptono Darmaji dan Hendy M. Fakhruddin, Op. Cit., hlm. 35.

${ }^{9}$ Keputusan Direksi PT Bursa Efek Surabaya Nomor SK-020/LGL/BES/XI/2004 tentang Peraturan Pencatatan Efek Nomor I.A.3 tentang Kewajiban Pelaporan Emiten.

10 Selain hal tersebut, sanksi suspensi juga dapat ditauhkan kepada emiten berkaitan dengan hasil audit laporan keuangan. Uraian lebih lanjut mengenai hal ini, baca: Sri Agung Surya Saputra, et all. "Perlindungan Hukum Terhadap Investor Atas Diberlakukannya Forced Delisting Oleh Bursa Efek Indonesia (Studi Kasus PT Davomas Abadi Tbk)", Diponegoro Law Journal, Volume 5, Nomor 3, Tahun 2016, hlm.4 http://www.ejournal-s1.undip.ac.id

${ }^{11}$ Keputusan Direksi PT Bursa Efek Indonesia Nomor Kep-00001/BEI/01-2014 tentang Peraturan Nomor I-A tentang Pencatatan Saham Dan Efek Bersifat Ekuitas Selain Saham yang Diterbitkan oleh Perusahaan Tercatat

${ }^{12}$ Nomor II angka1-2 Keputusan Direksi PT Bursa Efek Jakarta Nomor KEP-307/BEJ/07-2004 tentang Peraturan Nomor I-H tentang Sanksi.

${ }^{13}$ Keputusan Direksi PT Bursa Efek Jakarta Nomor Kep-308/Bej/07-2004 tentang Peraturan Peraturan Nomor I-I tentang Penghapusan Pencatatan (Delisting) dan Pencatatan Kembali (Relisting) Saham Di Bursa.

${ }^{14}$ Tjiptono Darmaji dan Hendy M.Fakhruddin, Op. Cit., hlm. 103-104. 
adanya 2 kondisi perusahaan tercatat yang dapat mengakibatkan terjadinya penjatuhan sanksi forced delisting. Kedua kondisi dimaksud yakni: ${ }^{15}$

1. Mengalami kondisi, atau peristiwa, yang secara signifikan berpengaruh negatif terhadap kelangsungan usaha Perusahaan Tercatat, baik secara finansial atau secara hukum, atau terhadap kelangsungan status perusahaan tercatat sebagai Perusahaan Terbuka, dan Perusahaan Tercatat tidak dapat menunjukkan indikasi pemulihan yang memadai;

2. Saham Perusahaan Tercatat yang akibat suspensi di Pasar Reguler dan Pasar Tunai, hanya diperdagangkan di Pasar Negosiasi sekurang-kurangnya selama 24 (dua puluh empat) bulan terakhir.

Berdasarkan ketentuan tersebut, tindakan forced delisting dapat dikenakan terhadap perusahaan tercatat yang telah mengalami sanksi suspensi selama dua puluh empat bulan.

Pengaturan mengenai sanksi suspensi pada prakteknya justru menimbulkan persoalan hukum. Persoalan hukum muncul karena BEI tidak memberikan pengaturan lebih lanjut mengenai tindakan yang dapat dikenakan kepada perusahaan tercatat yang telah mendapatkan sanksi suspensi selama lebih dari 24 bulan baik di sebagian pasar maupun di seluruh pasar. Dengan kata lain, persoalan hukum muncul karena BEI tidak mengatur secara jelas mengenai batas waktu maksimal pengenaan sanksi suspensi.

Data menunjukkan setidaknya terdapat dua perusahaan tercatat yang telah mengalami sanksi suspensi selama lebih dari 24 bulan, namun BEI tidak melakukan pencabutan sanksi suspensi dan tidak pula melakukan tindakan forced delisting. Kedua perusahaan tercatat dimaksud yakni PT. Berlian Laju Tanker Tbk (BLTA) dan PT. Leo Investement Tbk (ITTG). Efek BLTA telah berada dalam masa suspensi selama 4 tahun 7 bulan. Sementara itu, efek ITTG berada dalam masa suspensi selama 4 tahun 4 bulan.

Penjatuhan sanski suspensi kepada BLTA dilakukan oleh BEI pada 18 Februari 2013 sebagai akibat tidak dilakukannya pembayaran atas biaya

\footnotetext{
${ }^{15}$ Nomor III angka 3.1 Keputusan Direksi PT Bursa Efek Jakarta Nomor Kep-308/Bej/07-2004 tentang Peraturan Peraturan Nomor I-I tentang Penghapusan Pencatatan (Delisting) dan Pencatatan Kembali (Relisting) Saham Di Bursa.
} 
pencatatan tahunan. ${ }^{16}$ Sementara itu, ITTG mendapatkan sanksi suspensi sejak 18 Mei 2013 sebagai akibat perusahaan tidak memperoleh pendapatan usaha. ${ }^{17}$

Berdasarkan penelusuran yang dilakukan oleh peneliti, hingga penelitian ini disusun baik BLTA maupun ITTG belum mendapat kejelasan dari BEI. Kedua efek perusahaan tercatat dimaksud masih terkena tindakan suspensi selama lebih dari 48 bulan. BEI belum menentukan tindakan bagi BLTA dan ITTG meskipun efek kedua perusahaan tercatat telah berada dalam masa suspensi selama lebih dari dua puluh empat bulan.

Suspensi berkepanjangan sebagaimana dialami oleh BLTA dan ITTG sejatinya tidak perlu terjadi. Secara normatif, BEI dapat melakukan dua pilihan tindakan terhadap perusahaan tercatat yang telah mengalami suspensi selama sekurang-kurangnya dua puluh empat bulan. Kedua tindakan dimaksud yakni (1) pencabutan sanksi suspensi ${ }^{18}$ atau (2) tindakan penghapusan pencatatan secara paksa (forced delisting). ${ }^{19}$ Namun demikian, BEI tidak melakukan tindakan baik terhadap BLTA maupun ITTG.

Perusahaan tercatat yang terus-menerus berada dalam pengenaan sanksi suspensi berpotensi merugikan investor. Suspensi saham menimbulkan kerugian bagi investor mengingat investor tidak dapat lagi melakukan jual beli atas saham perusahaan tercatat. ${ }^{20}$ Akibatnya, investor mengalami kehilangan keuntungan

16 Pengumuman Nomor Peng-SPT-00002/BEI.PPR/02-2013 tentang Penghentian Sementara Perdagangan Efek PT Berlian Laju Tanker Tbk (BLTA). Secara lengkap pertimbangan penjatuhan sanksi suspensi tersebut berbunyi: "Bahwa Berkenaan dengan kewajiban Perusahaan Tercatat untuk melakukan pembayaran Biaya Pencatatan Tahunan (Annual Listing Fee) di tahun 2013, PT Berlian Laju Tanker Tbk (BLTA) belum melakukan pembayaran sebesar Rp. 110.000.000. Maka Bursa mengenakan sanksi penghentian sementara perdagangan Efek (suspensi) kepada PT Berlian Laju Tanker Tbk (BLTA) di seluruh Pasar sampai dengan dipenuhinya kewajiban pembayaran biaya pencatatan tahunan dan denda tersebut."

${ }^{17}$ Pengumuman Nomor Peng-SPT-00012/BEI.PPJ/05-2013 tentang Penghentian Sementara Perdagangan Efek PT Leo Investments Tbk. (ITTG). Secara lengkap, pertimbangan penjatuhan sanksi suspensi tersebut berbunyi: "Menunjuk Laporan Keuangan Interim PT Leo Investments Tbk. (Perseroan) per 31 Maret 2013 yang disampaikan kepada Bursa pada tanggal 30 April 2013, dimana dalam Laporan Keuangan tersebut Perseroan tidak memperoleh pendapatan usaha, PT Bursa Efek Indonesia memutuskan untuk melakukan penghentian sementara perdagangan Efek PT Leo Investments Tbk. (ITTG) di Seluruh Pasar mulai perdagangan Sesi I hari Rabu tanggal 1 Mei 2013."

${ }_{18}$ Baca Surat Edaran Nomor: SE-008/BEJ/08-2004 tentang Penghentian Sementara Perdagangan Efek Perusahaan Tercatat.

${ }^{19}$ Keputusan Direksi PT Bursa Efek Jakarta Nomor Kep-308/BEJ/07-2004 tentang Peraturan Nomor II tentang Penghapusan Pencatatan (Delisting) dan Pencatatan Kembali (Relisting) Saham Di Bursa

${ }^{20}$ Saham DGIK terkena suspensi, investor merugi, terdapat dalam http://investasi.kontan.co.id/news/sahamdgik-terkena-suspensi-investor-merugi, diakses pada 16 September 2017 
(capital loss). ${ }^{21}$ Pada konteks inilah perlindungan hukum bagi investor menjadi sangat penting.

Para investor tidak dapat melakukan tuntutan atau permintaan agar saham yang dimilikinya dibeli kembali (buyback) oleh perusahaan tercatat yang terkena sanksi suspensi. Hal tersebut antara lain disebabkan karena pembelian kembali saham oleh perusahaan hanya dapat dilakukan hingga batas maksimum 20 persen dari modal disetor tanpa persetujuan RUPS. Selain itu, saham hasil buyback dapat dialihkan kepada pihak lain baik dengan penjualan melalui bursa maupun melalui penjualan di luar bursa setelah 30 hari sejak buyback dilaksanakan seluruhnya. ${ }^{22}$

Pembelian kembali saham dalam kondisi perusahaan tercatat masih berada dalam sanksi suspensi menjadi sangat sulit untuk dilakukan mengingat perusahaan yang memperoleh sanksi suspensi biasanya berada dalam kondisi keuangan yang negatif. ${ }^{23}$ Selain itu, pengenaan sanksi suspensi berakibat pada memburuknya image perusahaan di mata investor sehingga pada masa mendatang efek milik perusahaan tercatat akan cenderung lebih sulit diterima oleh investor.

BEI sebagai Self Regulatory Organization memiliki kewenangan untuk mengatur para anggotanya sekaligus melakukan penegakan terhadap setiap peraturan yang telah dibuat. Bursa wajib untuk memastikan bahwa setiap peraturan yang telah dibuat mampu memberikan jaminan kepastian dan perlindungan hukum bagi setiap pihak yang berkepentingan. Dua pihak berkepentingan dalam hal ini terutama adalah pihak investor dan perusahaan tercatat. Namun demikian, pengaturan dan pelaksanaan sanksi suspensi justru menimbulkan persoalan hukum di dalam praktek. Ketiadaan batas waktu maksimal pengenaan sanksi suspensi berpotensi menimbulkan kerugian baik bagi pihak perusahaan tercatat maupun bagi pihak investor.

Berbeda dengan di Indonesia, pengenaan sanksi suspensi di Amerika Serikat oleh Securities Exchange Commision (SEC) hanya dapat dilakukan untuk jangka

\footnotetext{
${ }^{21}$ Cintya Christina Siahaan, Suspensi Perusabaan Efek oleb Bursa Efek Indonesia, http://ejournal.uajy.ac.id/7408/1/JURNAL.pdf, diakses pada 16 September 2017.

${ }_{22}$ Menimbang Untung Rugi Buyback Sabam, https://www.wartaekonomi.co.id/read15918/menimbanguntungrugi-buyback-saham.html, diakses pada 16 September 2017.

${ }^{23}$ Baca: Nomor III angka 3.1 Keputusan Direksi PT Bursa Efek Jakarta Nomor Kep-308/Bej/07-2004 tentang Peraturan Peraturan Nomor I-I tentang Penghapusan Pencatatan (Delisting) dan Pencatatan Kembali (Relisting) Saham Di Bursa.
} 
waktu tertentu yakni sepuluh hari. ${ }^{24}$ Kejelasan batasan waktu pengenaan sanksi suspensi di Amerika Serikat didasarkan pada motivasi utama dalam memberikan perlindungan hukum bagi investor.

\section{Rumusan Masalah}

Permasalahan yang dikaji dalam penelitian ini meliputi; Pertama, bagaimana pengaturan sanksi suspensi oleh BEI dan implikasinya terhadap kepastian hukum bagi perusahaan tercatat? Kedua, bagaimana implikasi atas ketiadaan batas waktu pengenaan suspensi terhadap perlindungan investor? Ketiga, bagaimana pengaturan mengenai batas waktu pengenaan suspensi di Amerika Serikat?

\section{Tujuan Penelitian}

Penelitian ini bertujuan untuk: Pertama, mengetahui dan menganalisis pengaturan batas waktu pengenaan sanksi suspensi oleh Bursa Efek Indonesia. Kedua, mengetahui dan menganalisis ketiadaan batas waktu pengenaan suspensi dan implikasinya terhadap perlindungan investor. Ketiga, mengetahui dan menganalisis pengaturan batas waktu pengenaan suspensi di Amerika Serikat.

\section{Metode Penelitian}

Metode yang digunakan dalam rangka menjawab rumusan masalah dalam penelitian ini adalah metode penelitian hukum normatif. Penelitian hukum normatif dilakukan melalui studi kepustakaan dengan mengumpulkan, mempelajari serta menganalisis data hasil penelitian yang relevan guna menjawab permasalahan penelitian. Data hasil penelitian kemudian disajikan secara kualitatif sesuai relevansinya dengan rumusan masalah. ${ }^{25}$

\footnotetext{
24 Investor Bulletin: Trading Suspension, SEC, Office of Investor Education and Advocacy, page 2 http://www.investor.gov diakses pada tanggal 30 Oktober 2016 pukul 12.10 WIB

${ }^{25}$ Johny Ibrahim, Teori dan Metodologi Penelitian Normatif, Banyumedia Publishing, Malang, 2006, hlm. 63.
} 


\section{Hasil Penelitian dan Pembahasan}

\section{Ketiadaan Batas Waktu Pengenaan Suspensi dan Kepastian Hukum bagi Perusahaan Tercatat}

Sesuai dengan kedudukannya sebagai self regulatory organization, ${ }^{26}$ Bursa Efek memiliki wewenang untuk membuat peraturan bagi seluruh anggotanya dan bagi kegiatan yang terjadi di dalam Bursa. Peraturan-peraturan yang dibuat oleh Bursa terutama dimaksudkan untuk mewujudkan dua hal. Pertama, terwujudnya perdagangan efek yang teratur, wajar dan efisien. ${ }^{27}$ Kedua, terwujudnya perlindungan hukum bagi investor. Peraturan Bursa Efek memiliki kekuatan hukum mengikat bagi setiap anggotanya beserta pihak-pihak terkait lainnya. ${ }^{28} \mathrm{Hal}$ demikian juga berlaku di Indonesia atas setiap peraturan yang dibuat oleh BEI.29

Salah satu peraturan penting yang dibuat oleh BEI adalah peraturan mengenai kewajiban-kewajiban bagi perusahaan tercatat. Dua di antara kewajiban perusahaan tercatat yakni kewajiban untuk melaksanakan keterbukaan ${ }^{30}$ dan kewajiban untuk membayar biaya pencatatan efek (listing fee). ${ }^{31}$

Berbagai macam sanksi berlaku terhadap pelanggaran atas kewajibankewajiban perusahaan tercatat. Jenis sanksi terhadap pelanggaran kewajiban oleh perusahaan tercatat meliputi: (1) peringatan tertulis I, (2) peringatan tertulis II, (3) peringatan tertulis III, (4) denda setinggi-tingginya lima ratus juta rupiah serta (5) penghentian sementara perdagangan Efek perusahaan tercatat di Bursa

26 Self Regulatory Organization (SRO) adalah lembaga yang diberi kewenangan untuk membuat peraturan yang mengatur para anggotanya. Baca: Iswi Hariyani dan R. Serfianto, Op. Cit., hlm. 21. Uraian secara lebih mendasar mengenai SRO dalam pasar modal baca pula: John Carson, Self Regulation in Securities Markets, The World Bank, Policy Research Working Paper Number 5542, January 2011.

27 Terwujudnya perdagangan efek yang teratur, wajar dan efisien merupakan tujuan dari kegiatan pembinaan, pengaturan serta pengawasan pasar modal sebagaimana ditentukan dalam Pasal 4 Undang-Undang Nomor 8 Tahun 1995 tentang Pasar Modal

${ }^{28}$ Tjiptono Darmaji dan Hendy M. Fakhruddin, Op. Cit., hlm. 35.

${ }^{29}$ Peraturan yang dibuat oleh BEI dalam hal ini terutama adalah berbagai macam Surat Keputusan dan Surat Edaran. Berdasarkan Pasal 7 ayat (4) Undang-Undang Nomor 12 Tahun 2011 tentang Pembentukan Peraturan Perundang-Undangan, Keputusan Direksi dan Surat Edaran dapat dikategorikan sebagai bentuk peraturan perundang-undangan yang sah.

${ }^{30}$ Yang dimaksud dengan kewajiban melaksanakan keterbukaan dalam hal ini adalah kewajiban bagi emiten (termasuk di dalamnya perusahaan tercatat) untuk melakukan pelaporan atas seluruh fakta material yang terjadi/dialami. Secara lebih rinci cakupan fakta material sebagaimana dimaksud telah diatur di dalam Pasal 6 Peraturan Otoritas Jasa Keuangan Nomor 31/POJK.04/2015 tentang Keterbukaan atas Informasi atau Fakta Material oleh Emiten atau Perusahaan Publik.

${ }^{31}$ Biaya pencatatan ini terdiri dari biaya pencatatan awal dan biaya pencatatan tahunan. 
(suspensi). ${ }^{32}$ Penjatuhan sanksi kepada perusahaan tercatat dilakukan setelah melalui tindakan penyelidikan ${ }^{33}$ terhadap indikasi pelanggaran yang dilakukan oleh perusahaan tercatat.

Berdasarkan pada peraturan BEI, sanksi suspensi dapat dijatuhkan antara lain kepada perusahaan tercatat yang melanggar kewajiban keterbukaan dan/atau melanggar kewajiban pembayaran biaya pencatatan. ${ }^{34}$ Hal demikian sebagaimana terjadi pada dua perusahaan tercatat yakni PT. Berlian Laju Tanker tbk (BLTA) dan PT. Leo Investment tbk (ITTG). Berdasarkan pengumuman resmi BEI, penjatuhan sanksi suspensi kepada BLTA disebabkan oleh pelanggaran kewajiban pembayaran biaya pencatatan tahunan sebesar Rp. 110.000.000,-. ${ }^{35}$ Sementara itu, ITTG mendapat sanksi suspensi sebagai akibat perusahaan tidak memperoleh pendapatan usaha. ${ }^{36}$

Secara normatif, BEI memiliki wewenang untuk melakukan dua pilihan tindakan terhadap perusahaan tercatat yang telah mengalami penjatuhan sanksi suspensi selama sekurang-kurangnya dua puluh empat bulan. Tindakan pertama yakni melakukan pencabutan atas sanksi suspensi. Tindakan kedua yakni melakukan penghapusan pencatatan secara paksa (forced delisting).

Pencabutan suspensi dapat dilakukan apabila perusahaan tercatat telah melaksanakan pemenuhan kewajiban atau kondisi perusahaan tercatat telah

\footnotetext{
32 Ketentuan lebih lengkap baca: Keputusan Direksi PT Bursa Efek Jakarta Nomor Kep-307/BEJ/072004 tentang Peraturan Nomor I-H tentang Sanksi.

33 Tindakan penyelidikan oleh BEI dalam hal ini sesuai dengan kewenangan BEI sebagai pengawas kegiatan pasar modal sehari-hari. Dalam cakupan yang lebih luas, pengawasan pasar modal dilakukan pula oleh Otoritas Jasa Keuangan $(\mathrm{OJK})$ sesuai dengan tugas fungsi serta wewenangnya dalam bidang pengawasan pasar modal. Uraian secara lebih mendalam mengenai ini baca: Inda Rahadiyan, Hukum Pasar Modal di Indonesia Pengawasan Pasar Modal Pasca Terbentuknya Otoritas Jasa Keuangan, Yogyakarta, UII Press, 2013, hlm. 113-142.

${ }^{34}$ Ketentuan secara lebih rinci, baca: Surat Edaran Nomor: SE-008/BEJ/08-2004 tentang Penghentian Sementara Perdagangan Efek Perusahaan Tercatat

35Pengumuman BEI Nomor Peng-SPT-00002/BEI.PPR/02-2013 tentang Pengumuman Penghentian Sementara Perdagangan Efek PT Berlian Laju Tanker Tbk (BLTA). Pengumuman tersebut menyatakan bahwa: "Berkenaan dengan kewajiban Perusabaan Tercatat untuk melakukan pembayaran Biaya Pencatatan Tabunan (Annual Listing Fee) di tabun 2013, PT Berlian Laju Tanker Tbk (BLTA) belum melakukan pembayaran. Maka Bursa mengenakan sanksi penghentian sementara perdagangan Efek (suspensi) kepada PT Berlian Laju Tanker Tbk. (BLTA) di seluruh Pasar sampai dengan dipenubinya kewajiban pembayaran biaya pencatatan tabunan dan denda sebesar sebesar R. 110.000.000,- tersebut.

36 Pengumuman Nomor.Peng-SPT-00012/BEI.PPJ/05-2013 tentang Penghentian Sementara Perdagangan Efek PT Leo Investments Tbk. (ITTG). Secara lengkap pengumuman tersebut menyatakan bahwa: "Menunjuk Laporan Keuangan Interim PT Leo Investments Tbk. (Perseroan) per 31 Maret 2013 yang disampaikan kepada Bursa pada tanggal 30 April 2013, di mana dalam Laporan Keuangan tersebut Perseroan tidak memperoleh pendapatan usaha, PT Bursa Efek Indonesia memutuskan untuk melakukan penghentian sementara perdagangan Efek PT Leo Investments Tbk. (ITTG) di Seluruh Pasar mulai perdagangan Sesi I hari Rabu tanggal 1 Mei 2013."
} 
mengalami perbaikan sebagaimana ditentukan oleh Bursa. ${ }^{37}$ Efek Perusahaan tercatat yang telah mengalami pencabutan sanksi suspensi selanjutnya dapat kembali diperdagangkan di Bursa.

Berkaitan dengan wewenang pencabutan sanksi suspensi oleh BEI ini, patut dicermati kondisi yang dialami oleh ITTG. Berdasarkan laporan keuangan yang dipublikasikan, ITTG tercatat telah memperoleh pendapatan usaha sejak September 2013. Artinya, secara normatif BEI dapat mencabut sanksi suspensi terhadap ITTG. Hal demikian sesuai dengan ketentuan Surat Edaran BEI Nomor: SE-008/BEJ/08-2004 tentang Penghentian Sementara Perdagangan Efek Perusahaan Tercatat.

\section{Tabel 1}

Pendapatan PT Leo Investments Tbk. (ITTG) Maret 2013-Juni 201738

\begin{tabular}{|c|c|c|}
\hline Tahun 2013 & Maret & - \\
& September & Rp. 5.433 .900 .000 \\
Tahun 2014 & Maret & Rp. 4.237 .200 .000 \\
& September & Rp. 5.966 .989 .500 \\
Tahun 2015 & Maret & Rp. 1.900 .812 .000 \\
& September & Rp. 21.291 .597 .000 \\
Tahun 2016 & Maret & Rp. 99.000.000 \\
& September & Rp. 99.000.000 \\
Tahun 2017 & Maret & Rp. 123.464.640 \\
& September & (Belum dipublikasikan) \\
\hline
\end{tabular}

Hingga laporan penelitian ini disusun, Bursa belum melakukan pencabutan sanksi suspensi terhadap ITTG. Hal demikian bertolak belakang dengan ITTG yang telah menyampaikan laporan keuangan dan mencatatkan sejumlah pendapatan usaha. ITTG tercatat telah mengalami sanksi suspensi selama 4 tahun 4 bulan.

Sanksi suspensi yang berkepanjangan selama lebih dari dua puluh empat bulan sejatinya tidak perlu terjadi. Hal demikian dapat dipahami mengingat BEI memiliki kewenangan untuk melakukan pencabutan sanksi suspensi. Selain itu, BEI juga telah mengatur adanya kewenangan untuk melakukan penghapusan

\footnotetext{
${ }^{37}$ Baca Surat Edaran Nomor: SE-008/BEJ/08-2004 tentang Penghentian Sementara Perdagangan Efek Perusahaan Tercatat.

${ }^{38}$ Laporan Keuangan Auditan PT Leo Investments Tbk. (ITTG) tahun 2013-2017, http://idx.co.id
} 
pencatatan ${ }^{39}$ secara paksa (forced delisting) terhadap perusahaan tercatat yang telah mengalami suspensi selama lebih dari 24 (dua puluh empat) bulan.

Penghapusan pencatatan dapat dilakukan oleh BEI terhadap perusahaan tercatat yang mengalami dua hal, yakni: (1) mengalami kondisi, atau peristiwa, yang secara signifikan berpengaruh negatif terhadap kelangsungan usaha Perusahaan Tercatat, baik secara finansial atau secara hukum, atau terhadap kelangsungan status Perusahaan Tercatat sebagai Perusahaan Terbuka, dan Perusahaan Tercatat tidak dapat menunjukkan indikasi pemulihan yang memadai. (2) Saham Perusahaan Tercatat akibat suspensi di Pasar Reguler dan Pasar Tunai, hanya diperdagangkan di Pasar Negosiasi sekurang-kurangnya selama 24 bulan terakhir. ${ }^{40}$ Berdasarkan pada ketentuan tersebut maka secara normatif Bursa dapat melakukan tindakan penghapusan pencatatan terhadap perusahaan tercatat yang telah berada dalam masa suspensi selama sekurang-kurangnya selama 24 bulan.

Berkaitan dengan pengaturan mengenai tindakan forced delisting, penjatuhan sanksi suspensi kepada BLTA sekiranya menjadi contoh yang penting dan menarik untuk dikaji. BEI menjatuhkan sanksi suspensi kepada BLTA sebagai akibat tidak dibayarnya biaya pencatatan tahunan (annual listing fee). Penjatuhan suspensi tersebut sebagaimana dimuat dalam pengumuman resmi BEI:41

"Berkenaan dengan kewajiban Perusahaan Tercatat untuk melakukan pembayaran Biaya Pencatatan Tahunan (Annual Listing Fee) di tahun 2013, PT Berlian Laju Tanker Tbk (BLTA) belum melakukan pembayaran. Maka Bursa mengenakan sanksi penghentian sementara perdagangan Efek (suspensi) kepada PT Berlian Laju Tanker Tbk (BLTA) di seluruh Pasar sampai dengan dipenuhinya kewajiban pembayaran biaya pencatatan tahunan dan denda sebesar sebesar Rp.110.000.000,-- tersebut."

Sanksi suspensi diberlakukan bagi BLTA terhitung sejak 18 Februari 2013. Hingga saat laporan penelitian ini disusun maka efek BLTA telah berada dalam kondisi suspensi selama 4 tahun 7 bulan.

\footnotetext{
${ }^{39}$ Terdapat dua jenis tindakan penghapusan pencatatan yang dikenal di dalam pasar modal. Pertama yakni penghapusan pencatatan oleh perusahaan tercatat secara sukarela (voluntary delisting). Kedua yakni penghapusan pencatatan secara paksa oleh Bursa Efek (forced delisting). Uraian secara lebih lanjut mengenai ini, baca: Tjiptono Darmadji dan Hendy M. Fakhrudin, Op. Cit., hlm. 70

40 Keputusan Direksi PT Bursa Efek Jakarta Nomor Kep-308/BEJ/07-2004 tentang Peraturan Nomor I-I tentang Penghapusan Pencatatan (Delisting) dan Pencatatan Kembali (Relisting) Saham Di Bursa

${ }^{41}$ Pengumuman BEI Nomor Peng-SPT-00002/BEI.PPR/02-2013 tentang Pengumuman Penghentian Sementara Perdagangan Efek PT Berlian Laju Tanker Tbk (BLTA).
} 
Kondisi yang dialami oleh BLTA dan ITTG setidaknya memunculkan dua pertanyaan mendasar. Pertama, berapakah batas maksimum pengenaan sanksi suspensi oleh BEI kepada perusahaan tercatat? Kedua, tindakan apakah yang akan dilakukan oleh BEI terhadap perusahaan tercatat yang telah mengalami sanksi suspensi secara berkepanjangan (lebih dari dua puluh empat bulan)? Pertanyaan demikian menjadi penting dan relevan karena suspensi yang berkepanjangan akan berimplikasi pada kepastian hukum bagi perusahaan tercatat dan perlindungan bagi investor.

Apabila dicermati, suspensi secara berkepanjangan sebagaimana dialami oleh BLTA dan ITTG sejatinya tidak perlu terjadi. Pendapat demikian didasarkan pada argumentasi bahwa BEI telah menentukan adanya tindakan yang dapat dilakukan terhadap perusahaan-perusahaan tercatat yang telah mengalami suspensi selama sekurang-kurangnya 24 bulan.

Sesuai dengan kewenangannya sebagai SRO, BEI dapat mencabut sanksi suspensi atau dapat pula melakukan penghapusan pencatatan secara paksa (forced delisting) terhadap perusahaan-perusahaan tercatat yang mengalami kondisi tertentu. Tindakan forced delisting dapat dilakukan oleh BEI kepada perusahaan tercatat yang telah mengalami suspensi selama sekurang-kurangnya 24 (dua puluh empat) bulan dan efeknya hanya diperdagangkan di pasar negosiasi. ${ }^{42}$

Secara mendasar seluruh peraturan yang dibuat oleh BEI sejatinya dilakukan dalam rangka mewujudkan dua tujuan. Pertama, terwujudnya perdagangan efek yang teratur, wajar dan efisien. ${ }^{43} \mathrm{Kedua}$, terwujudnya perlindungan investor.

Perdagangan efek terselenggara secara teratur apabila seluruh mekanisme perdagangan efek dilakukan berdasarkan suatu aturan tertentu. ${ }^{44}$ Berdasarkan pada Undang-Undang Pasar Modal dan struktur pasar modal Indonesia, maka BEI merupakan suatu SRO yang berwenang menetapkan dan menegakkan peraturanperaturan baik mengenai perdagangan efek maupun mengenai hal lainnya.

\footnotetext{
42 Keputusan Direksi PT Bursa Efek Jakarta Nomor Kep-308/BEJ/07-2004 tentang Peraturan Nomor I-I tentang Penghapusan Pencatatan (Delisting) dan Pencatatan Kembali (Relisting) Saham Di Bursa

${ }^{43}$ Pasal 4 Undang-Undang Republik Indonesia Nomor 8 Tahun 1995 tentang Pasar Modal

44 Penjelasan atas Pasal 4 Udang-Undang Republik Indonesia Nomor 8 Tahun 1995 tentang Pasar Modal
} 
Peraturan Bursa dalam hal ini meliputi pula seluruh kewajiban bagi pelaku pasar modal dan pihak terkait (termasuk perusahaan tercatat).

Kembali pada persoalan pengaturan sanksi suspensi, maka persoalan yang paling mendasar sejatinya muncul karena ketiadaan batas waktu pengenaan sanksi suspensi bagi perusahaan tercatat. BEI melalui Keputusan Direksi PT Bursa Efek Jakarta Nomor Kep-308/BEJ/07-200445 dan Surat Edaran Nomor: SE-008/BEJ/08$2004^{46}$ hanya menentukan adanya dua pilihan tindakan. Pertama, BEI dapat melakukan pencabutan atas sanksi suspensi. Kedua, BEI dapat melakukan forced delisting. BEI dapat melakukan tindakan forced delisting kepada perusahaan tercatat yang telah mengalami tindakan suspensi selama sekurang-kurangnya 24 (dua puluh empat) bulan.

Terlepas dari kedua pilihan tindakan sebagaimana telah disebutkan, tidak ada pengaturan mengenai batas waktu maksimal bagi pengenaan sanksi suspensi. Kondisi demikian tentu akan berimplikasi pada persoalan jaminan kepastian hukum bagi perusahaan tercatat yang pada akhirnya akan berimplikasi pula pada perlindungan investor.

\section{Ketiadaan Batas Waktu Pengenaan Sanksi Suspensi dan Implikasinya terhadap Perlindungan Investor}

Seluruh peraturan yang dibuat oleh BEI sejatinya dilakukan dalam rangka mewujudkan dua hal. Pertama, terwujudnya perdagangan efek yang teratur, wajar dan efisien. Kedua, terwujudnya perlindungan bagi investor. ${ }^{47}$ Ketiadaan pengaturan batas waktu pengenaan sanksi suspensi bagi perusahaan tercatat akan berakibat pada lemahnya perlindungan hukum ${ }^{48}$ bagi investor. ${ }^{49}$ Hal demikian

\footnotetext{
${ }^{45}$ Keputusan Direksi PT Bursa Efek Jakarta Nomor Kep-308/BEJ/07-2004 tentang Peraturan Nomor I-I tentang Penghapusan Pencatatan (Delisting) dan Pencatatan Kembali (Relisting) Saham Di Bursa

46 Surat Edaran Nomor: SE-008/BEJ/08-2004 tentang Penghentian Sementara Perdagangan Efek Perusahaan Tercatat.

${ }^{47}$ Pasal 4 Undang-Undang Republik Indonesia Nomor 8 Tahun 1995 tentang Pasar Modal

48 Berdasarkan pendapat R. La Porta, bentuk perindungan hukum yang diberikan oleh suatu negara memiliki dua sifat. Pertama, perlindungan hukum yang bersifat pencegahan. Kedua, perlindungan hukum yang bersifat pemberian hukuman. Uraian lebih lanjut mengenai hal ini, baca: Hilda Hilmiah Dimyati, "Perlindungan Hukum Bagi Investor Pasar Modal”, artikel dalam Jurnal Citra Hukum, Volume 1 Nomor 2, tahun 2014, hlm. 342.

${ }^{49}$ Berkaitan dengan persoalan mengenai perlindungan hukum bagi investor ini patut pula untuk dicermati uraian dalam salah satu artikel Journal of Financial Economics berikut ini: 'investor protection turns out to be crucial because, in many countries, expropriation of minority shareholders and creditors by the controlling shareholders is extensive. When outside investors finance firms, they face a risk and sometimes near certainty that the returns on their investment will never materialize because the controlling shareholders or managers expropriate them." Lihat: La Porta, et all., "Investor Protection and Corporate
} 
dapat dipahami mengingat pengenaan sanksi suspensi berakibat pada terhentinya aktivitas perdagangan atas efek perusahaan tercatat di Bursa. Terhentinya perdagangan efek di bursa tentu akan berakibat pada munculnya kerugian (capital loss) bagi investor. ${ }^{50}$

Sebagaimana telah disinggung, perusahaan tercatat yang mengalami sanksi suspensi pada dasarnya tidak mengetahui dengan pasti mengenai batas waktu maksimal berlangsungnya sanksi suspensi. Dalam kaitan ini pelaksanaan perbaikan managemen perusahaan sebagai salah satu syarat pencabutan sanksi suspensi ${ }^{51}$ juga tidak dibatasi oleh jangka waktu tertentu. Kondisi demikian tentu berimplikasi terhadap lemahnya perlindungan investor.

Pada saat efek perusahaan tercatat mengalami suspensi di seluruh pasar, investor sama sekali tidak dapat melakukan aktivitas perdagangan atas efek perusahaan tercatat. Peraturan Bursa mengenai suspensi menentukan bahwa suspensi dapat dilakukan atas perdagangan efek di pasar regular, ${ }^{52}$ pasar tunai ${ }^{53}$ serta pasar negosiasi ${ }^{54}$ secara kumulatif. Ini berarti, investor yang memiliki saham perusahaan tercatat yang terkena sanksi suspensi di seluruh pasar akan berada dalam kondisi diam (menunggu). Keadaan diam atau menunggu ini berakibat pada hilangnya harapan keuntungan.

Governance", artikel dalam Journal of Financial Economics 58, (2000) 3-27, http://www.economics.harvard.edu/files/faculty/56_IPCorpGov.pdf

${ }^{50} \mathrm{Hal}$ demikian sejalan pula dengan pendapat para praktisi pasar modal, di antaranya yakni hasil analisa dari analis First Capital sebagaimana termuat dalam berita "Saham DGIK terkena suspensi, investor merugi" http://investasi.kontan.co.id/news/saham-dgik-terkena-suspensi-investor-merugi, diakses pada 16 September 2017

${ }^{51}$ Baca Surat Edaran Nomor: SE-008/BEJ/08-2004 tentang Penghentian Sementara Perdagangan Efek Perusahaan Tercatat

52 Definisi pasar reguler menurut Keputusan Direksi PT Bursa Efek Indonesia No: Kep-00023/BEI/042016, tentang Peraturan Nomor II-A tentang Perdagangan Efek Bersifat Ekuitas adalah pasar dimana perdagangan Efek di Bursa dilaksanakan berdasarkan proses tawar-menawar secara lelang yang berkesinambungan (continuous auction market) oleh Anggota Bursa Efek dan penyelesaiannya dilakukan pada Hari Bursa ke-3 setelah terjadinya Transaksi Bursa $(\mathrm{T}+3)$.

53 Pasar tunai adalah pasar yang diperuntukkan bagi transaksi yang dilakukan dalam rangka pemenuhan kewajiban anggota bursa yang gagal dalam penyelesaian transaksi efek, berdasarkan prinsip pembayaran dan penyerahan seketika (cash and carry).

54 Definisi pasar negosiasi menurut Keputusan Direksi PT Bursa Efek Indonesia No: Kep00023/BEI/04-2016, tentang Peraturan Nomor II-A tentang Perdagangan Efek Bersifat Ekuitas adalah pasar di mana perdagangan Efek Bersifat Ekuitas di Bursa dilaksanakan berdasarkan tawar menawar langsung secara individual dan tidak secara lelang yang berkesinambungan (non continuous auction market) dan penyelesaiannya dapat dilakukan berdasarkan kesepakatan Anggota Bursa Efek. 
Sama halnya dengan kegiatan investasi dalam sektor lain, pada dasarnya setiap investor yang melakukan investasi di pasar modal melalui pembelian efek (saham) memiliki motivasi untuk memperoleh keuntungan. Harapan untuk memperoleh keuntungan umumnya didasarkan pada selisih antara harga beli dengan harga jual efek. Berbeda dengan para pemegang saham yang sejak awal merupakan pendiri perseroan, ${ }^{55}$ para investor pasar modal mengharapkan adanya suatu keuntungan jangka pendek (capital gain) dari selisih harga beli dan harga jual efek. Harapan keuntungan demikian akan hilang apabila efek perusahaan tercatat mengalami suspensi secara berkepanjangan tanpa suatu kepastian.

\section{Pengaturan Mengenai Batas Waktu Pengenaan Sanksi Suspensi di Amerika Serikat}

Secara universal sebagaimana juga berlaku di Amerika Serikat, penjatuhan sanksi suspensi dilakukan dalam rangka memberikan perlindungan hukum bagi kepentingan publik dan investor. Penjatuhan sanksi suspensi di Amerika Serikat merupakan kewenangan dari Securities Exchange Commission sesuai dengan kedudukannya sebagai pengawas pasar modal. ${ }^{56}$

SEC memberikan pengaturan mengenai batasan waktu yang jelas dalam hal penjatuhan sanksi suspensi bagi perusahaan tercatat. Sanksi suspensi bagi perusahaan tercatat dilakukan maksimal selama sepuluh hari bursa. Berdasarkan peraturan mengenai perdagangan, SEC dapat menjatuhkan sanksi suspensi atas terjadinya pelanggaran-pelanggaran yang dilakukan oleh perusahaan tercatat. Penjatuhan sanksi suspensi oleh SEC secara garis besar diakibatkan oleh terjadinya pelanggaran prinsip keterbukaan dalam hal penyampaian informasi kepada publik. Penjatuhan sanksi suspensi dilakukan terhadap berbagai pelanggaran dan/atau kondisi tertentu yang meliputi: ${ }^{57}$

1. A lack of current, accurate, or adequate information about the company, for example, when a company is not current in its fillings of periodic reports;

${ }^{55}$ Para pemegang saham ini memiliki motivasi investasi berupa keuntungan jangka panjang. Selain itu, para pemegang saham dalam posisi yang mayoritas pada umumnya juga memiliki motivasi untuk melakukan pengendalian perseroan.

56 Suspension Archive, SEC http://www.sec.gov/litigation/suspension/suspensionarchive/ susparch2013.shtml diakses pada tanggal 30 Oktober 2016.

57 Investor Bulletin: Trading Suspension, SEC, Office of Investor Education and Advocacy, page 1 http:/ /www.investor.gov diakses pada tanggal 30 Oktober 2016. 
2. Questions about the accuracy of publicly available information, including in company press release and reports, about the company's current operational status, financial condition, or business transactions;

3. Questions about trading in the stock, including trading by insiders, potential market manipulation, and the ability to clear and settle transactions in the stocks.

Berdasarkan ketentuan tersebut, secara umum sanksi suspensi dijatuhkan kepada perusahaan tercatat yang terbukti melakukan pelanggaran terhadap keterbukaan informasi. Selain itu, suspensi juga dilakukan berkaitan dengan terjadinya perdagangan secara tidak fair.

Sanksi suspensi diberikan untuk jangka waktu maksimum sepuluh hari kepada perusahaan tercatat yang terbukti melakukan pelanggaran. ${ }^{58}$ Batasan waktu maksimum sepuluh hari dalam penjatuhan sanksi suspensi ini berarti bahwa sanksi suspensi akan berakhir dalam jangka waktu sepuluh hari tersebut. Selama periode suspensi, SEC tidak akan memberikan pernyataan apa pun kepada publik.

Setelah sanksi suspensi kepada suatu perusahaan tercatat dinyatakan berakhir, pada umumnya para perantara pedagang efek akan melarang para investor untuk kembali melakukan perdagangan atas saham perusahaan tercatat dimaksud di pasar Over the Counter (OTC market) sampai dengan perusahaan tercatat mampu memenuhi persyaratan-persyaratan tertentu. ${ }^{59}$ Hal ini dilakukan dalam rangka memberikan perlindungan hukum bagi investor.

Berbeda dengan BEI yang belum memberikan pengaturan mengenai batas waktu maksimum pengenaan suspensi, SEC di Amerika Serikat mengatur dengan tegas mengenai batas waktu maksimum sepuluh hari dalam hal penjatuhan sanksi suspensi. Selain memberikan ketentuan batasan waktu pengenaan suspensi, para perantara pedagang efek (broker-dealers) juga memiliki peran penting dalam menentukan kelanjutan perdagangan saham perusahaan tercatat pasca berakhirnya sanksi suspensi. Perantara pedagang efek akan memastikan kondisi perusahaan tercatat sebelum merekomendasikan kepada para investor untuk kembali melakukan perdagangan atas saham perusahaan tercatat pasca mengalami sanksi suspensi.

\footnotetext{
${ }^{58}$ Ibid., hlm. 2

${ }^{59}$ Ibid., A broker-dealer must file a Form-211 with the Financial Industry Regulatory Authority (FINRA).
} 
Berdasarkan pada perbedaan mendasar antara pengaturan batas waktu penjatuhan sanksi suspensi antara Indonesia dan Amerika Serikat, sekiranya Otoritas Jasa Keuangan (OJK) dan BEI dapat melakukan koordinasi baik mengenai pembuatan peraturan baru maupun mengenai revisi peraturan yang telah ada sebelumnya. Pendapat demikian didasarkan pada argumentasi bahwa koordinasi antara OJK dengan BEI dalam hal pembuatan dan revisi peraturan Bursa telah diatur di dalam Peraturan Otoritas Jasa Keuangan Nomor 46/POJK.04/2016 tentang Tata Cara Pembuatan Peraturan oleh Bursa Efek. POJK dimaksud mengatur mengenai tata cara permohonan izin oleh Bursa Efek Indonesia kepada Otoritas Jasa Keuangan dalam hal pembuatan maupun perubahan peraturan.60

Berkaitan dengan pengaturan mengenai penjatuhan sanksi suspensi, setidaknya terdapat dua hal yang dapat dilakukan oleh BEI. Pertama, BEI dapat melakukan revisi dengan terlebih dahulu menyampaikan permohonan kepada OJK. Kedua, BEI dapat mengajukan permohonan izin kepada OJK dalam rangka menerbitkan peraturan baru. Peraturan baru dimaksud utamanya adalah peraturan khusus mengenai tindakan-tindakan tertentu yang harus dilakukan oleh BEI terhadap perusahaan-perusahaan tercatat yang telah mengalami suspensi selama lebih dari 24 (dua puluh empat) bulan.

\section{Penutup}

Peraturan Bursa Efek Indonesia mengenai penghentian perdagangan sementara (suspensi) dapat dikatakan masih belum memberikan jaminan kepastian hukum bagi perusahaan tercatat. Peraturan Bursa Efek Indonesia mengenai suspensi tidak memberikan batasan waktu atas lamanya pengenaan sanksi suspensi. Tidak terdapat pengaturan yang jelas mengenai batas waktu tindakan suspensi bagi perusahaan tercatat yang telah mendapatkan sanksi suspensi selama lebih dari 24 bulan. PT. Leo Investments Tbk (ITTG) yang telah terkena sanksi suspensi di seluruh pasar selama 4 tahun 4 bulan dan PT. Berlian Laju Tanker Tbk (BLTA) yang telah terkena sanksi suspensi di seluruh pasar

\footnotetext{
${ }_{60}$ Pasal 2 ayat (2) Peraturan Otoritas Jasa Keuangan Nomor 46/POJK.04/2016 tentang Tata Cara Pembuatan Peraturan oleh Bursa Efek
} 
sekunder selama 4 tahun 7 bulan hingga saat ini belum mendapatkan kepastian tindakan dari Bursa Efek Indonesia.

Ketiadaan batas waktu pengenaan sanksi suspensi bagi perusahaan tercatat berimplikasi terhadap kurangnya perlindungan investor. Ketiadaan batas waktu pengenaan sanksi suspensi mengakibatkan investor tidak dapat melakukan perdagangan atas saham perusahaan tercatat. Kondisi demikian terus berlangsung selama perusahaan tercatat masih berada dalam masa suspensi, sehingga menimbulkan kerugian (capital loss).

Batas waktu pengenaan sanksi suspensi di Amerika Serikat diatur secara tegas. Sanksi suspensi di Amerika Serikat berlaku dalam jangka waktu sepuluh hari bursa. Kejelasan batas waktu pengenaan sanksi suspensi oleh Securities Exchange Commission (SEC) di Amerika Serikat memberikan jaminan kepastian hukum yang lebih baik bagi perusahaan tercatat yang pada akhirnya akan lebih menjamin perlindungan hukum bagi investor.

\section{Daftar Pustaka}

\section{Buku}

Balfaz, Hamud M., Hukum Pasar Modal di Indonesia, PT. Tata Nusa, Jakarta, 2010. Black, Henry Champel, Black's Law Dictionary, Sixth Edition, ST. Paull, Minn, 1990.

Darmaji, Tjiptono dan Hendy M. Fakhruddin, Pasar Modal Di Indonesia Pendekatan Tanya Jawab, Edisi Pertama, Salemba Empat, Jakarta, 2001.

Gisymar, Najib A., Insider Trading Dalam Transaksi Efek, PT. Citra Aditya Bakti, Bandung, 1999.

Hariyani, Iswi dan R. Serfianto, Buku Pintar Hukum Pasar Modal: Strategi Tepat Investasi Saham, Obligasi, Waran, Right, Opsi, Reksadana dan Produk Pasar Modal Syariah, Visimedia, Jakarta, 2001.

Ibrahim, Johny, Teori dan Metodologi Penelitian Normatif, Banyumedia Publishing, Malang, 2006.

Pramono, Nindyo, Bunga Rampai Hukum Bisnis Aktual, PT. Citra Aditya Bakti, Bandung, 2006.

Rahadiyan, Inda, Hukum Pasar Modal di Indonesia Pengawasan Pasar Modal Pasca Terbentuknya Otoritas Jasa Keuangan, Cetakan Pertama, UII Press, Yogyakarta, 2014. , Pokok-Pokok Hukum Pasar Modal di Indonesia, UII Press, Yogyakarta, 2017. 
Sitompul, Asril, Pasar Modal: Penawaran Umum dan Permasalahannya, Citra Aditya Bakti, Bandung, 1999.

\section{Jurnal}

Dimyati, Hilda Hilmiah, "Perlindungan Hukum Bagi Investor Pasar Modal", artikel dalam Jurnal Citra Hukum, Volume 1 Nomor 2, Tahun 2014.

La Porta, et all., "Investor Protection and Corporate Governance", artikel dalam Journal of Financial Economics, 58, (2000) 3-27.

Moammar, Yasser, et all. “Tanggung Jawab Direksi Perusahaan Dalam Hal Terjadi Suspensi Saham Di Bursa Efek Indonesia yang Merugikan Pihak Investor (Studi Kasus: Suspensi Saha, PT Buana Listya Tama)", artikel dalam Diponegoro Law Journal, http://ejournal3.undip.ac.id

Saputra, Sri Agung Surya, et all. "Perlindungan Hukum Terhadap Investor Atas Diberlakukannya Forced Delisting Oleh Bursa Efek Indonesia (Studi Kasus PT Davomas Abadi Tbk)", artikel dalam Diponegoro Law Journal Volume 5, Nomor 3, Tahun 2016, http:/ / www.ejournal-s1.undip.ac.id

Siahaan, Cintya Christina, "Suspensi Perusahaan Efek oleh Bursa Efek Indonesia", artikel dalam Naskah Publikasi dalam http:/ / e-journal.uajy.ac.id,

\section{Peraturan Perundang-Undangan}

Undang-Undang Republik Indonesia Nomor 8 Tahun 1995 tentang Pasar Modal

Undang-Undang Republik Indonesia Nomor 10 Tahun 2004 tentang Pembentukan Peraturan Perundang-Undangan

Peraturan Otoritas Jasa Keuangan Nomor 31/POJK.04/2015 tentang Keterbukaan atas Informasi atau Fakta Material oleh Emiten atau Perusahaan Publik

Peraturan Otoritas Jasa Keuangan Nomor 46/POJK.04/2016 tentang Tata Cara Pembuatan Peraturan oleh Bursa Efek

Surat Edaran Nomor: SE-008/BEJ/08-2004 tentang Penghentian Sementara Perdagangan Efek Perusahaan Tercatat

Keputusan Direksi PT Bursa Efek Surabaya Nomor SK-020/LGL/BES/XI/2004 tentang Peraturan Pencatatan Efek Nomor I.A.3 tentang Kewajiban Pelaporan Emiten

Keputusan Direksi PT Bursa Efek Indonesia Nomor Kep-00001/BEI/01-2014 tentang Peraturan Nomor I-A tentang Pencatatan Saham Dan Efek Bersifat Ekuitas Selain Saham yang Diterbitkan oleh Perusahaan Tercatat

Keputusan Direksi PT Bursa Efek Jakarta Nomor KEP-307/BEJ/07-2004 tentang Peraturan Nomor I-H tentang Sanksi

Keputusan Direksi PT Bursa Efek Jakarta Nomor Kep-308/Bej/07-2004 tentang Peraturan Peraturan Nomor I-I tentang Penghapusan Pencatatan (Delisting) dan Pencatatan Kembali (Relisting) Saham Di Bursa 
Keputusan Direksi PT Bursa Efek Indonesia No: Kep-00023/BEI/04-2016, tentang Peraturan Nomor II-A tentang Perdagangan Efek Bersifat Ekuitas

\section{Data Internet}

John Carson, Self Regulation in Securities Markets, The World Bank, Policy Research Working Paper Number 5542, January 2011, http:/ / worldbank.org

Pengumuman Nomor Peng-SPT-00002/BEI.PPR/02-2013 tentang Penghentian Sementara Perdagangan Efek PT Berlian Laju Tanker Tbk (BLTA), http:/ /idx.co.id

Pengumuman Nomor Peng-SPT-00012/BEI.PPJ/05-2013 tentang Penghentian Sementara Perdagangan Efek PT Leo Investments Tbk. (ITTG), http:/ /idx.co.id

Anonim, Saham DGIK terkena suspensi, investor merugi, terdapat dalam http:/ / investasi.kontan.co.id, diakses pada 16 September 2017

Anonim, Menimbang Untung Rugi Buyback Saham, https: / / www.wartaekonomi.co.id.

Teguh Hidayat, Sekilas Mengenai Suspensi Saham, terdapat dalam http:/ / www.teguhhidayat.com

Investor Bulletin: Trading Suspension, SEC, Office of Investor Education and Advocacy, http://www.investor.gov

Laporan Keuangan Auditan PT Leo Investments Tbk. (ITTG) tahun 2013-2017, http://idx.co.id

SEC, Suspension Archive, http:/ / www.sec.gov

SEC, Investor Bulletin: Trading Suspension, SEC, Office of Investor Education and Advocacy, http://www.investor.gov 